\title{
Ao Mestre com Carinho
}

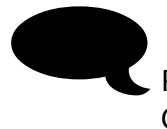

Waldomiro Vergueiro

Professor Titular, Doutor em Ciências da Comunicação Observatório de Histórias em Quadrinhos da ECA-USP
Falar sobre a importância de Moacy Cirne não só para o desenvolvimento das pesquisas sobre histórias em quadrinhos no meio acadêmico, mas, também, para uma compreensão maior das histórias em quadrinhos como forma de manifestação artística legítima e com características próprias seria, basicamente, enfatizar o óbvio. Ou "chover no molhado", para utilizarmos uma linguagem mais popular que tanto agradava a Cirne.

Em seus longos anos de dedicação aos quadrinhos, como docente do Departamento de Comunicação Social da Universidade Federal Fluminense e secretário de redação da Revista de Cultura Vozes, Moacy Cirne foi uma prova viva de como as histórias em quadrinhos são importantes na sociedade. Em suas aulas e palestras, mesclava seu extenso conhecimento do meio com uma ferina ironia, um olhar crítico muito acurado e uma intensa paixão pelos produtos da $9^{a}$ Arte. Mesmo após se aposentar e se afastar de suas atividades docentes, retornando para seu estado natal, o Rio Grande do Norte, continuou a se dedicar às áreas que sempre o atraíram durante sua vida profissional, especialmente as histórias em quadrinhos e a poesia, produzindo ainda vários obras, que vieram a se somar às muitas que já havia escrito - como se sabe, foi de sua autoria o primeiro livro sobre quadrinhos publicado no Brasil, no início da década de 1970. Poucos pesquisadores conseguiram atingir tal nível de comprometimento com a pesquisa e valorização das histórias em quadrinhos. Seu falecimento, em janeiro de
2014, representou uma imensa perda para todos que nos interessamos pela arte gráfica sequencial.

Uma produção intelectual $\mathrm{da}$ magnitude daquela deixada por Moacy Cirne não irá simplesmente desaparecer com seu desaparecimento físico. Seus livros, artigos científicos, poemas, entrevistas nos mais variados veículos continuarão ainda a influenciar as próximas gerações de pesquisadores. No entanto, mais do que deixar que a obra desse pesquisador fale por si mesma - e ela não apenas fala, ela grita em altos brados, incomodando os ouvidos daqueles que se recusam a escutála -, é sem dúvida necessário fazer uma reflexão sobre ela, buscando compreender suas proposições e ampliar seu alcance.

Foi essa a motivação a guiar o prof. Marcos Antonio da Silva, da Faculdade de Filosofia, Ciências e Letras da Universidade de São Paulo, amigo de longa data de Moacy Cirne, a propor a organização de um livro sobre ele, em que todos os aspectos de sua produção fossem analisados e discutidos. A essa empreitada ele se dedicou com afinco nos três anos seguintes ao falecimento do pensador, em exitoso esforço, que foi concluído no segundo semestre de 2018, com o lançamento do livro Moacy Cirne, Moacys Cirnes: Quadrinhos, Cinema, Literatura \& Cia. (1966-2013), publicado pela LCTE Editora, de São Paulo.

Moacy Cirne foi, sem dúvida, um homem plural, daí a pluralidade do título da obra. Professor, pesquisador, agitador cultural, crítico literário e cinematográfico, poeta, produtor de fanzines, militante,

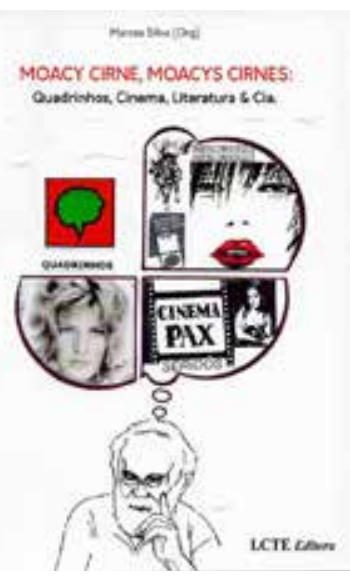

SILVA, Marcos (Org.). Moacy Cirne, Moacys Cirnes: quadrinhos, cinema, literatura \& cia. São Paulo: LCTE Editora, 2018. 410p. 
torcedor do Fluminense Futebol Clube. Seu campo de interesse e seu leque de atividades durante suas décadas de atuação foram muito vastos e variados. O livro busca refletir essa pluralidade, apresentando capítulos sobre essa diversidade de atividades, sem perder de vista a unicidade do pensamento de Moacy Cirne, um homem de fortes convicções socialistas.

O livro é composto por 34 capítulos (incluindo-se aqui um prefácio e uma apresentação), elaborado por igual número de autores, que se revezam discutindo o pensador potiguar e sua obra, em abordagens que vão desde o tom bastante pessoal, recordatório mesmo, daqueles que, além de admirar a obra, também privaram da amizade e convivência do autor, ao enfoque acadêmico, daqueles que conheceram mais de perto a obra e não tiveram o privilégio de partilhar a intimidade de Moacy.

Ambas as abordagens se completam de uma maneira bastante harmoniosa, permitindo ao leitor conhecer não apenas os meandros do pensamento do mais insigne criador do poema-processo, mas também os diversos aspectos de sua personalidade, suas idiossincrasias, como ele era no seu dia-a-dia, quando

(...) havia sempre uma emoção renovada, ao contar e recontar histórias vivenciadas ou ao rememorar cenas de um ou outro filme especial, que na verdade, eram tantos no seu histórico; ao vibrar e novamente vibrar com seu time, e mesmo negando ser um torcedor radical, era sempre veemente na sua defesa. (pag. 13).

Pouco mais um terço dos capítulos do livro é dedicado às contribuições de Cirne sobre as histórias em quadrinhos, o que é bastante compreensível, uma vez que foi no estudo dos comics que ele mais se notabilizou e onde se concentra a maior parte de suas publicações, desde o livro inicial, de 1970 - A explosão criativa dos quadrinhos -, até o último sobre esse tema, publicado trinta e cinco anos depois
- A escrita dos quadrinhos. Os demais capítulos dividem-se entre suas explorações poéticas, cinéfilas (e abordagens mais pessoais (poesias em homenagem ao autor, por exemplo, e capítulos que falam do torcedor do Fluminense - "Para Moacy, um bravo tricolor", elaborado por Tarcísio Gurgel, amigo de infância de Cirne, embora um inveterado flamenguista -, e de reminiscências pessoais (como, por exemplo, os capítulos "Nosso amigo Moacy Cirne" e "O Moacy Cirne que eu conheci", elaborados, respectivamente, por Jarbas Martins e Alderico Leandro). Trata-se de um leque de contribuiçóes bastante diverso, e mesmo quando o homenageado não trata diretamente do homenageado, percebe-se que é este a inspiração para o texto.

Completam o volume uma lista de livros e plaquetes publicados por Cirne (na qual, eventualmente, pude identificar uma pequena falha da obra: na lista não consta o título Quadrinhos, sedução e paixão, de 2000, o meu predileto dentre os livros de Cirne), além de dois anexos. $\mathrm{O}$ primeiro contém talvez a primeira produção acadêmica do professor da UFF, intitulada “Teoria e crítica em Mário de Andrade", um ensaio datado de 1966, com o qual Cirne recebeu o Prêmio Esso de Literatura. Já o segundo traz uma longa entrevista de Cirne, concedida ao organizador do livro em junho de 1998, em que ele discorre sobre sua vida e trajetória intelectual.

Moacy Cirne, Moacys Cirnes constitui uma adequada e merecida homenagem a um pensador que tanto trouxe para o estudo e para a valorização das histórias em quadrinhos, realizando um trabalho intelectual que poucos conseguiram atingir no Brasil. Juntamente com as próprias produçóes do autor, o livro merece ser incluído nas bibliotecas de todos os estudiosos a apreciadores da narrativa desenhada. 